\title{
Analysis of Mismatch Losses Arising from Crystalline and Amorphous Silicon PV Panels: An Indian Experience
}

\author{
Prajit Paul ${ }^{1}$ \\ Department of Electronics and \\ Communication Engineering \\ Asansol Engineering College, Asansol \\ Asansol, India \\ Soumendu Kumar Ghosh ${ }^{2}$ \\ Krishnendu Ghosh ${ }^{3}$ \\ Dipankar Mukherjee ${ }^{4}$ \\ 2,3,4 Department of Electronics and Telecommunication Engineering \\ Bengal Engineering and Science University, Shibpur, Howrah, India
}

\begin{abstract}
In order to configure the right kind of Photovoltaic (PV) panel/PV arrays in a typical Indian climatic condition, electrical characterizations of different kinds of PV modules were carried out by the authors under varying levels of incident solar radiation (insolation). The experimental results reveal that amorphous silicon modules definitely enjoy advantages of lower mismatch losses with respect to crystalline silicon counterparts.
\end{abstract}

\section{Introduction}

India has abundant solar resources receiving 2500-3000 hours of sunshine every year with a potential of generating $20 \mathrm{MW} / \mathrm{km}^{2}$, but the major part of the available sunshine is diffused in nature (especially in Eastern and North Eastern states). This calls for appropriate attention to be directed towards the configuration of a Solar Photovoltaic (SPV) system so that Energy Security [1,2] as envisaged by Ministry Of New and Renewable Energy Sources (MNRES) and the Jawaharlal Nehru Solar Mission (JNSM) can be achieved within the target period. In the above back drop, the designers of large area SPV systems carefully have to consider the impact of Mismatch losses in different technology PV modules. Therefore Mismatch effects at the level of PV panel configuration has been considered by the authors of this paper under actual roof top insolation in the form of:

a) Relative Power Losses (R.P.L.) and

b) Shadowing Losses.

There is some work dealing with these mismatch losses, but most of them only examine the losses under Standard Test Conditions (STC - irradiance: $1000 \mathrm{~W} / \mathrm{m}^{2}$; AM 1.5 spectrum; module temperature: $25^{\circ} \mathrm{C}$ ). This has been currently revived through the efforts of W. Damm et al [3] of the University of Oldenburg where the group has investigated R.P.L. values of PV modules in Non-standard climatic conditions.

\section{Experimental Configurations}

With the aforesaid direction of investigation, winter morning sessions with good values of clearness index were chosen for conducting the experiments on a pair of low-wattage (10 watts) PV modules on the roof of the departmental buildings. For both Single Crystalline Silicon (c-Si) modules and Amorphous Silicon (a-Si) Modules, the following configurations were used for R.P.L. estimates:

a) Current-Voltage $(I-V)$ characteristics of $1^{\text {st }} \mathrm{C}$ Si module.

b) I-V characteristics of $2^{\text {nd }} c$-Si module. 
c) I-V characteristics of above modules in series combination.

d) I-V characteristics of above modules in parallel combination.

e) Aforesaid set of experiments were repeated for a-Si modules at the same level of insolation $\left(400 \mathrm{~W} / \mathrm{m}^{2}\right)$ on the plane of modules.

Experiments (a) to (e) were repeated for insolation level of $500 \mathrm{~W} / \mathrm{m}^{2}$ and $600 \mathrm{~W} / \mathrm{m}^{2}$ also. The electrical characteristics were utilized to estimate the R.P.L. [4, 5] arising in series and parallel combination of the modules.

\section{Results}

In this section Table 1 shows estimated values of R.P.L. in series and parallel combination of both c-Si and a-Si modules at an insolation of $400 \mathrm{~W} / \mathrm{m}^{2}$.

Table 1. Relative power loss estimates at insolation of $400 \mathrm{~W} / \mathrm{m}^{2}$

\begin{tabular}{|c|c|c|}
\hline $\begin{array}{c}\text { Type of } \\
\text { Module }\end{array}$ & $\begin{array}{c}\text { R.P.L. } \\
\text { Series }\end{array}$ & $\begin{array}{c}\text { R.P.L. } \\
\text { Parallel }\end{array}$ \\
\hline $\begin{array}{c}\text { Crystalline } \\
\text { Silicon } \\
\text { Module }\end{array}$ & $12.29 \%$ & $7.99 \%$ \\
\hline $\begin{array}{c}\text { Amorphous } \\
\text { Silicon } \\
\text { Module }\end{array}$ & $2.5 \%$ & $4.5 \%$ \\
\hline
\end{tabular}

Table 2 lists up the basic electrical parameters of a PV module that have significantly contributed to the $1^{\text {st }}$ mismatch effect (R.P.L.) in a-Si PV modules with increasing insolation during the later part of the day.

Table 2. Electrical parameters contributing to R.P.L. values of amorphous silicon modules

\begin{tabular}{|c|c|c|c|}
\hline \multirow{2}{*}{ Parameters } & \multicolumn{3}{|c|}{ Insolation } \\
\cline { 2 - 4 } & $\begin{array}{c}\mathbf{4 0 0} \\
\mathbf{W} / \mathbf{m}^{2}\end{array}$ & $\begin{array}{c}\mathbf{5 0 0} \\
\mathbf{W} / \mathbf{m}^{2}\end{array}$ & $\begin{array}{c}\mathbf{6 0 0} \\
\mathbf{W} / \mathbf{m}^{2}\end{array}$ \\
\hline$\frac{d I_{s c}}{I_{s c}}$ & $0.70 \%$ & $7.40 \%$ & $0.50 \%$ \\
\hline$\frac{d V_{m}}{V_{m}}$ & $3.10 \%$ & $0.78 \%$ & $1.58 \%$ \\
\hline R.P.L. Series & $2.50 \%$ & $5.96 \%$ & $1.40 \%$ \\
\hline $\begin{array}{c}\text { R.P.L. } \\
\text { Parallel }\end{array}$ & $4.50 \%$ & $0.80 \%$ & $3.60 \%$ \\
\hline
\end{tabular}

The following set of figures depicts the effect of Shadowing losses on c-Si and a-Si modules. Figure 1 depicts the I-V curve of a c-Si module at an insolation of $250 \mathrm{~W} / \mathrm{m}^{2}$. The fully illuminated characteristics of the module is compared with the characteristics obtained with

a) $15 \%$ shadowing (85\% illumination)

b) $30 \%$ shadowing (70\% illumination).

Testing of a-Si module under $100 \%$ illumination, $85 \%$ illumination and $70 \%$ illumination at an insolation of $250 \mathrm{~W} / \mathrm{m}^{2}$ gave 3 sets of $\mathrm{I}-\mathrm{V}$ characteristics. These curves are depicted in Figure 2.

The percentage of illumination to which the c-Si and a-Si modules were subjected, is mentioned in the I-V curves in Figure 1 and Figure 2.

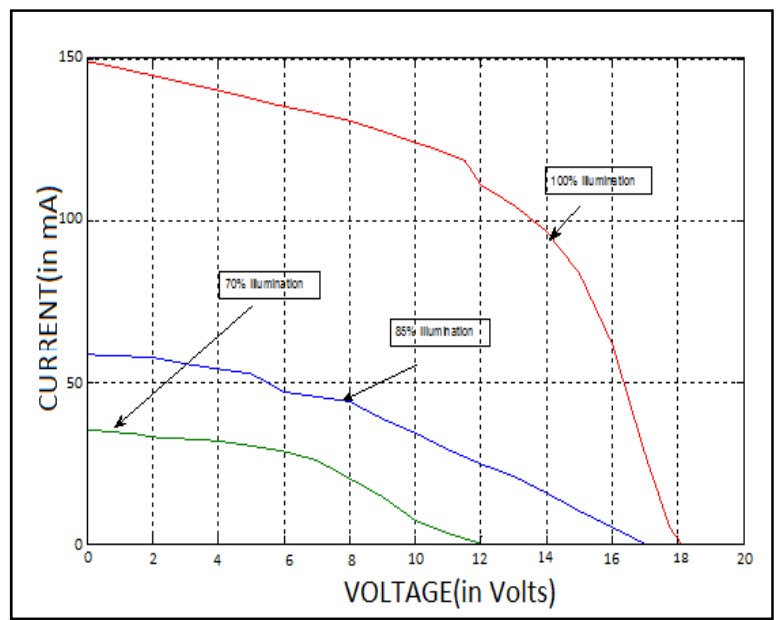

Figure 1. Crystalline silicon module under shadow effect at insolation of $250 \mathrm{~W} / \mathrm{m}^{2}$

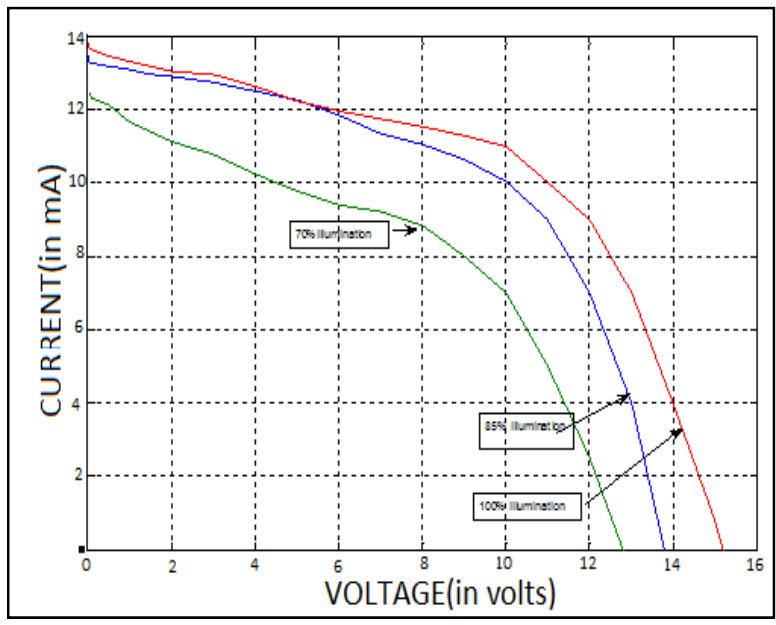

Figure 2. Amorphous silicon module under shadow effect at insolation of $250 \mathrm{~W} / \mathrm{m}^{2}$

\section{Concluding Remarks}

From Table 1, it is seen that the R.P.L. values estimated vary from $8 \%$ to $12 \%$ for c-Si modules whereas this mismatch reduced to only about $2 \%$ to 
$6 \%$ for a-Si modules at an insolation of $400 \mathrm{~W} / \mathrm{m}^{2}$. From Table 2, it is found that the magnitude of R.P.L. values for series string depends principally on the relative dispersion of Short-Circuit currents of individual modules while this magnitude for parallel string is principally affected by the relative dispersion of Peak power voltages of the individual modules. Thus, R.P.L. values for parallel combination of PV modules although lower than its series counterparts, as is evident from Table 1 have to be accounted for and not neglected as opined by some investigating system designers [3]. However, these roof-top experiments have to be repeated for varying sky conditions in West Bengal before such a selecting criterion for a-Si modules can be adopted for configuring PV panels. Also, a similar experimental configuration as depicted in section 2 has to be performed by the authors at identified levels of insolations, typically experienced in average Indian Climatic Conditions.

Regarding the shadow effect on these low wattage modules, it can be clearly envisaged from Figure 1 and Figure 2 that the effect of shadowing is much less detrimental for a-Si module (relative percentage reduction of peak-power is only $40 \%$ compared to c-Si modules) compared to c-Si module of same wattage. Thus, it is evident that a-Si modules are the obvious choice over c-Si counterpart in compelling situations involving partial shadowing.

However the configurations of the large area PV arrays are assuming greater significance in view of the upcoming new buildings in the urban areas which are the platforms for Building Integrated Photovoltaic (BIPV) Systems [6,7]. It is expected that the Amorphous Silicon PV modules, in aforesaid deployments will have an edge over the Crystalline Silicon PV modules in this part of the subcontinent.

\section{Acknowledgements}

We gratefully acknowledge the technical assistance rendered by Mr. Suvankar Bose in various stages of the experimental configurations.

\section{References}

[1] Rakesh Bhalla (Jan 2010) 'Modalities for Financing of Off-Grid Solar Power Projects under Jawaharlal Nehru National Solar Mission', IREDA NEWS, vol.7, No.1and2, pp.18-22.

[2] J.Madiath and M.Tuckwell (July-Sept 2005) ' $N G O$ Experiences in Village Energy Security in Orissa', IREDA News, vol.2, No.3, pp.39-41.

[3] Wolfgang Damm, Detlev Heinemann and Detlef Pukrop, Department of Physics, University of Oldenburg, Germany (Dec2011) Personal Communication.
[4] D.Mukherjee and S.Chakraborty (2004), Fundamentals of Renewable Energy Systems, $1^{\text {st }}$ ed., Newage Publishers.

[5] H.Saha, G. Bhattacharya and D.Mukherjee (1998), Mismatch Losses in Series Combinations of Si-Solar Cell Modules, Solar Cells, 25, pp.143-153.

[6] D.Paul, PhD Thesis, Engineering Faculty of Bengal Engineering and Science University, Shibpur,Awarded in Feb 2011.

[7] P.Eiffert et al (Feb 2000), BIPV for commercial and Institutional Structures, A Sourcebook for Architects and Engineers, NREL/BK-520-252572. 